\title{
UTILIZATION OF COASTAL ZONE IN INDONESIA. PRESENT STATUS OF OYSTER, SEAWEED AND COCKLE CULTURE
}

by

\author{
WARD ANA ISMAIL ${ }^{1}$
}

\begin{abstract}
Maricullure in coastal zone, such as the bays, inlets, or lagoons in coral reef is becoming more important in the world fishery activities.

In Indonesia, some culture experiments are being conducted, such as for oyster (Crassostrea tuculata BORN) in Banten Bay, and seaweed (Eucheuma spinosum) in Samaringa Islands (Central Sulawesi) and Talang islands (Riau Archipelago), while culture of cockle (Anadara granose LIN.) based on a simple method have been conducted by local fishermen from Ketapang (West Jawa) since several years ago.

Some preliminary results of culture experiments are given.
\end{abstract}

\section{INTRODUCTION}

The steady increase of the world population, even though is being slowed down by family planning programmes in most countries, makes the demand of food product increase as well.

In the past the provision of food was terrestrial products oriented. Ground cultivations, land farming, etc. have been instituted and customized, where as catching fish is merely a hunting procedure.

If one thinks that $71 \%$ of the world surface is covered by sea water, besides the link of food chain shows that organic matters are the product of photosynthesis by marine microscopic plants existing as far as $200 \mathrm{~m}$ depth, it is logical that one should emphasize the probable maximum utilization of the described evidences.

It is known that the average sea water productivity is about 250 gram dried organic matter per $\mathrm{m}^{2}$ per year (250 g C/m²/year, KESTEVEN \& LAEVASTU 1958). The average production of ground cultivation is usually believed to be 380 grams. Compared to this, the capability of the sea to produce organic matters is encouraging. That is, if it is related to the area of the ocean and that primary production forms the first link of the food chain.

1) Marine Fisheries Research Institute, Jakarta. 


\section{WARDANA ISMAIL}

The world marine fisheries activities are weighted mostly on catching the fish and developing its techniques and equipments which resulted in overfishing evidences such as decreasing fish sizes and age classes. This is caused by the premature catches. Another evidence is the sharp drops of CPUE.

In Indonesian waters such evidences have been known recently in the Malacca Strait area and in the north coast of Jawa, where the number of fishermen and their activities are very high. As an example the CPUE (in kg/day) of the Malacca Strait were respectively 176.3 (1973), 155.9 (1974), and 118.4(1975).

One way, among others, to fulfill the need of food and to overcome the above problems is to develop mariculture for several fish species, shellfish, seaweeds and other marine products which are economically and technically feasible.

Mariculture also provides:

1. new employment opportunity,

2. substitutive effort in overfished areas and for fishermen loosing their job due to the limitation or prohibition of certain types of fishing (e.g. bagan). Besides, it can be executed in infertile islands having productive waters, where agriculture is impossible.

3. the mariculture products could produce new export commodities after its succesful development.

\section{CONDITIONS OF CULTURE BEDS}

\section{Area}

The areas are the coastal waters of continental shelfs. Therefore, mariculture activities in the area could be considered as coastal aqua-culture, which is another way to utilize the coastal zone.

\section{Water Condition}

The water conditions are as follows: lagoons.

- having high productivity, especially those of estuaries, bays, inlets or

- natural beds of the species intended to be cultured, especially for shellfish and seaweeds.

- accessible markets and available manpower.

Jawa, with her dense population (120 millions constituting $60 \%$ of the population of Indonesia) is a potential market for agricultural and fishery products. 
The result of mariculture survey, conducted in April 1975 and March 1976 by a team from Japan International Cooperation Agency (JICA) and Marine Fisheries Research Inst. (LPPL) which were supervized by Dr. ARAKAWA and Dr. KAFUKU respectively, show that some places have excellent opportunities to be developed as mariculture grounds, such as:

a. The Ban ten Bay for shellfish culture emphasizing on spat collection, and for floating cage culture of Lates calcarifer.

b. Ketapang (Mauk) for Anadara granosa culture.

c. The Pari Island off Jakarta for rearing of Siganus spp. Epinephelus spp., and Eritmochelys imbricata in its lagoons.

d. Kalianget (East Madura) is quite suitable for pen-culture.

e. The Strait of Madura, especially those of Kenjeran and Sidoarjo for Anadara, Amosium, and Placuna placenta culture.

f. Benoa in southern Bali is suitable for pen-culture of milk-fish, whereas the Bay of Terima in the northern part is suitable for both pen and floating net cage culture of ornamental fishes.

g. The Bay of Ratai in Lampung for floating net cage culture of Lates, Epinephelus, and Lutianus.

In regard to the geographical situation, some areas are suitable for mariculture purposes, such as:

a. The Riau Archipelago for seaweeds, (especially Eucheuma), pearl oysters, and marine fishes.

b. Certain places in the East part of Sumatera for shellfish.

c. The Nusa Tenggara Archipelago for seaweeds, pearl, edible oysters, and turtles.

d. The southern part of Sulawesi for pearl oyster and seaweeds.

e. Some areas in Kalimantan are suitable for shellfish culture.

f. The eastern part of Indonesia (Mollucas) is generally suitable for pearl oyster, seaweeds, and fish culture.

\section{MARICULTURE ACTIVITY}

The present mariculture activity in Indonesia can be considered as an undeveloped stage and is far behind compared with that of other countries. For example, the culture of laver (Porphyra spp.) and oyster (Crassostrea gigas) in Japan has been conducted for over 200 years. And also the oyster culture in Oostershelde, the Netherlands.

In Indonesia mariculture activity is conducted by fishermen at Ketapang, Mauk (West Jawa), conducted in a very simple method, i.e. 


\section{WARDANA ISMAIL}

dividing the beds by using bamboo fence for rearing Anadara granosa L. This effort began some 20 - 25 years ago, limited with a 20 ha culture ground. The production reaches 20 - 30 tons per culture season (May - December). The culture activity is not always conducted every year. It depends upon the availability of spats, which have an interval of 2 - 3 years (IsMAIL 1970).

The seaweed culture (Eucheuma spp.) in Maumere (East Nusatenggara) started a few years ago, with transplanting and bottom farm methods based on vegetative reproduction.

The pearl oyster culture is relatively more developed, since it was conducted through a joint-venture programme with the Japanese in Buton (South Sulawesi) and Aru Island (Moluccas).

Fishermen of the Seribu Islands are at present conducting "culture" of several coral fishes, such as Epinephelus, Siganus and some species of Labridae (Wrasses), which is more like a storage culture effort (i.e. keeping fish inside bamboo cages locally called dongdang) without any treatment to increase its economical value before being sold (marketed). The effort of rearing turtles (Eritmochelys imbricata) also exist in this area, eventhough incidentally conducted. The juvenils are caught in the Bangka Biliton waters. Several experimental mariculture activities have been and are still being conducted in Indonesia, for example:

- the oyster (Crassostrea sp.) culture experiment was conducted by the Fisheries Regency Service of Jepara (Central Jawa) in the sixties, some 10 to 15 years ago. A preliminary experiment of seaweed culture (Eucheuma sp.) in Pari Island was done some 10 years ago by Mr. SURJODINOTO. These two experiments were not continued.

- the Eucheuma spinosum culture experiment is being conducted by the LPPL in cooperation with a private company in Samaringa Island., Menui Archipelago (Central Sulawesi;. The method use is based on vegetative reproduction system of which seedplants are attached on monofilament ropes extended below the sea surface and kept submerged at all time. The preliminary results (July - Oct. 1975) show that the average positive growth was $2.898 \%$ per day meaning 2.356 weight increment in one month, 5.552 times within 2 months, or 13.080 times within 3 months provided there is no disturbance. (MUBARAK 1975).

In the Philippines a figure of $2 \%$ growth increment per day is set out to ascertain the profitability of seaweed culture effort (TRONO 1974).

During the experiment seedplant could be taken out of any part of the plants, but harvesting should be done only by cutting the plant's top ends leaving its bases (the thick ends) (MUBARAK 1975). The same experiment is 
being conducted in Telang Island (Riau Archipelago) as well. This is in cooperation with the Marine Colloid Inc.

Experimental oyster (Crassostred cuculata) culture in Banten Bay conducted by the LPPL started 2 - 3 years ago and is still in progress. The method is an off-bottom culture utilizing rafts. The preliminary results show that there are significant differences among the 3 types of collectors used. The cement coated tiles collected more spats compared with those of lime coated tiles or ordinary tiles. The spats on lime coated tiles are easily detached. The difference in spat numbers related with the depth (range from $25 \mathrm{~cm}$ below the water surface down to $150 \mathrm{~cm}$ with an interval of $25 \mathrm{~cm}$ ) is also significant during the experiment (ISMAIL \& SUBAGIO 1973).

The results of the experiments in Banten Bay could be summarized as follows:

- The average number of spats attached onto the tiles was 26 spats/piece (May 1975). The gonad maturity condition exists every month. During the months of January, May and October highest gonad maturity apeared having percentages of 30,39 and 26\% respectively.

- Fattining seasons occured on October 1975 and January 1976, though the specimen of $9-18$ months old did not show any evident growth. The coliform bacterial numbers are increasing towards the estuarine (FATUCHRI etal 1975).

\section{PROBLEMS IN MARICULTURE}

There are problems which will be encountered in mariculture activity. Those are, among others, as follows:

1. The problems of culture techniques, such as:

- proper construction and establishment of culture equipment, which are economically feasible,

- lack of biological and behaviourial data of the species being cultured,

- limited facility for experiment or research,

— limited expertise and experienced experts in mariculture.

\section{Budget}

The budget for mariculture is reasonally high. The natural factors such as unfavourable wheather conditions which are difficult to forecast could give disaster. Research and development in culture techniques needs a lot of money, therefore, government as well as private assistanships are necessary. 


\section{WARD AN A ISMAIL}

\section{Marketing}

The increase of mariculture products sometimes is not well balanced by the demands or proper price. This might discourage further effort. A sales promotion is probably needed.

\section{Conflicts with other fishing activities}

As mariculture activities develop in coastal areas wherein fishing activities already axist, the probability of conflict is great. The establishment of Anadara culture beds as well as culture rafts will obstruct some fishing gear activities. Therefore, a proper coastal zone management is necessary, besides the understanding and participations of the fishermen.

\section{Security}

Theft and disturbance on mariculture equipments always exist, especially in remote areas. Therefore, regulations are necessary to protect mariculture activities.

\section{Pollution}

Water pollution, especially that of the coastal areas, is recently increasing in several countries, together with industrial development, coastal establishment and garbage dumping, besides, oil spills from transportations.

The effects of pollution on species being cultured are:

- the increase of mortality,

- the decrease of growth rate,

- defective maturity, spawning and recruitments,

- degradation of product quality caused by contamination.

\section{CONCLUSION}

— Mariculture effort is significantly a proper way of utilizing coastal zone, which is most suitable for areas showing overfishing. And also feasible as a substantial effort in regions having unprofitable agricultural activities.

- Extensive studies should be conducted emphasizing on species feasible for culture. Geographically there are vast areas suitable for mariculture establishment.

- Pollution is a hindrance especially for mariculture. Therefore, environmental management, such as those relating to industrial waste treatment, is necessary. 


\section{UTILIZATION OF COASTAL ZONE IN INDONESIA}

\section{BIBLIOGRAPHY}

ANONYMUS, 1971. Mariculture. Yearbook of Science and Technology, McGraw-Hill.

ARAKAWA, Y. and H. OKADA 1975. Report on Marine culture Survey in Indonesia (1975 March 28 April 17). LPPL 1/75 - Pl.052/75: 39-77.

FATUCHRI, M., W. ISMAIL and WASILUN 1975. A Study of Crassostrea cuculata Born in Banten Bay in relation with its possibility for culture. LPPL. $-P l .05$ 7/75.

ISMAIL, W. 1968. Cockle culture at Ketapang, Banten (West Java). IPFC Proced. 13 th.

ISMAIL, W. 1970. Observasi pemeliharaan kerang darah (Anadara granosa L.) di Ketapang (Mauk). LPPL.-Pl. 012/70.

ISMAIL, W. and B. SUBAGIO 1973. Percobaan pengumpulan benih (spat collection) tiram (oyster) di Pulau Pari dan Teluk Banten. LPPL. -Pl.040/73.

KORR1NGGA, P. The basic principles of Shellfish farming on the Continental Coast of Europe. Repr. from the Procs. of Symposium on Mollusca, part III.

MUBARAK, M. 1975. Percobaan pemeliharaan Eucheuma spinosum di Pulau Samaringa, Menui (Sulawesi Tengah). (Juli-Oktober 1975). LPPL. Pl.054/75: 78-101.

SHIGENO, K. 1970. Problems of Prawn Culture in Japan. IPFC/C70/Sym.8, Bangkok. 